Nunt. Antiquus, Belo Horizonte, v. 14, n. 1, p. 87-109, 2018

\title{
Autobiografias literárias na poesia de exílio: a recepção de Ovídio em Camões ${ }^{1}$
}

\section{Literary Autobiographies in the Poetry of Exile: the Reception of Ovid in Camões}

\author{
Júlia Batista Castilho de Avellar² \\ Universidade Federal de Minas Gerais, Belo Horizonte, Minas Gerais / Brasil \\ juliabcavellar@gmail.com
}

Resumo: Os Tristia (“Tristezas"), de Ovídio, são considerados a obra fundadora da lírica de exílio na tradição ocidental. Nessa coletânea de elegias, Ovídio realiza sua última metamorfose e assume uma persona de exilado, que lamenta os sofrimentos em Tomos, cidade às margens do Mar Negro, nos limites do Império Romano. Este artigo investiga a (auto)representação do poeta como exilado, a permanência dessa imagem na tradição literária e sua importância para a poesia de exílio posterior. Será analisada a recriação empreendida por Camões na Elegia III, destacando-se os pontos de diálogo com a obra ovidiana e as inovações instauradas pelo poeta português. Camões adota uma persona ovidiana ao cantar seus males de ausência e efetua uma releitura da poesia dos Tristia. Assim, a presente abordagem centra-se na recepção do "mito" da vida e do exílio de Ovídio na poesia camoniana e, sobretudo, nas construções que circundam a figura do poeta exilado.

Palavras-chave: exílio; Ovídio; Camões; recepção dos clássicos; autobiografia.

Abstract: The Tristia ('Sadnesses') of Ovid are considered the founding work of the genre poetry of exile in the Western tradition. In this collection of elegies, Ovid makes his last metamorphosis, and assumes the persona of an exiled first-person speaker: he mourns his sufferings in Tomis, city on the edge of the Roman Empire, on the margins of next to the Black Sea. This paper aims to study the poet's self-representation as

\footnotetext{
${ }^{1}$ Agradeço ao meu orientador, Prof. Matheus Trevizam, pela leitura cuidadosa do texto, e ao Prof. Sérgio Alcides, pelas referências teóricas sobre a poesia de Camões. ${ }^{2}$ Doutoranda em Literaturas Clássicas e Medievais pelo Pós-Lit e bolsista CAPES.
} 
exiled, the development of this image in the literary tradition, and the meaning of such representation to the ulterior poetry of exile. We will analyze Camões' reception of Ovid in his Elegy III, and identify both the similarities and the innovations the Portuguese poet implemented to the poetry of exile's genre. Camões adopts an Ovidian persona to express the sorrows of absence, and thus makes a new reading of the Tristia. The present approach focuses on Camões' responses to the "myth" of Ovid's life and exile, and investigates the creation of an image of exiled poet.

Keywords: Exile; Ovid; Camões; Classical Reception; Autobiography.

\section{Introdução}

Ovídio é considerado pelos estudiosos em geral como o precursor do gênero poesia de exílio na tradição ocidental. ${ }^{3}$ Muito embora essa temática exista na literatura desde Homero, fazendo-se presente na poesia de Alceu, na prosa consolatória helenística e nas cartas de Cícero, os Tristia e as Epistulae ex Ponto ovidianos são obras em que há uma elaboração sistemática do tema, por meio de poemas em primeira pessoa, nos quais a figura de poeta/autor se apresenta como exilado. ${ }^{4}$ Além disso, a poesia ovidiana gerou inúmeras respostas posteriores, podendo-se dizer, como Ingleheart (2011, p. 2), que Ovídio assume o papel de exilado arquetípico. Ele reúne em seus versos, segundo André (1992, p. 82), os elementos e tópoi fundamentais que, posteriormente, caracterizarão a literatura de exílio. ${ }^{5}$

A qualificação de Ovídio como o cantor, por excelência, do exílio adquire sabor especial caso se considere que estudos recentes, inaugurados por Fitton Brown (1985), têm posto em xeque a real ocorrência do

\footnotetext{
${ }^{3}$ Por exemplo, Williams (2006, p. 234); Claassen (2009, p. 174); Ingleheart (2011, p. 1). ${ }^{4}$ Veja-se Ingleheart $(2011$, p. 1), que ainda afirma ser Ovídio o mais antigo exemplo de exilado cuja identidade primária é aquela de escritor.

${ }^{5}$ Entre os tópoi listados por André (1992, p. 53-54), estão a contraposição dos lugares de outrora aos atuais; o canto como forma de proteção à agressão do espaço em torno; a incapacidade de cantar; a memória como fonte de inspiração que é negada pela terra de exílio; a ênfase nos momentos da partida e da viagem, pois representam a consciência da separação; a tirania e a repressão como causas do desterro; a afirmação da injustiça da punição; a nova comunidade descrita como bárbara e selvagem; os problemas de comunicação e desconhecimento da língua; a esperança de regresso; o desejo de morrer na pátria.
} 
banimento do autor-empírico. A ausência de documentos e registros oficiais do exílio ovidiano e sua não menção por contemporâneos, ${ }^{6}$ bem como o caráter nitidamente literário das descrições do local estimularam a possibilidade de a relegação ter sido inteiramente uma construção literária e ficcional, e não uma realidade do autor-empírico. Ora, numa perspectiva que deixa espaço para uma possível não ocorrência do exílio, torna-se ainda mais instigante pensar a fixação da figura de Ovídio como exilado, pois isso suscita reflexões sobre como uma obra poética pode ser capaz de interferir na constituição da imagem e da vida de seu autor. Em suma, sobre como a ficção pode produzir efeitos no mundo real.

Independentemente da real ocorrência do banimento, ${ }^{7}$ os escritos ovidianos tiveram tamanha potência a ponto de fundar um "mito" de exílio do poeta - "mito" de fundamentação literária. Como assinala Claassen (1988, p. 169), a criação do mito do exílio é um triunfo poético. Ele demonstra o poder da poesia em construir mundos e formar uma imagem em torno do autor. Evidência disso é Ovídio, até hoje, ser associado à figura de exilado. Esse "mito", porém, não se esgota nas elegias ovidianas: ele foi aos poucos sendo desenvolvido pela recepção posterior da obra. A cada retomada da temática do exílio por autores posteriores, a cada nova obra do gênero lírica de exílio, também a poesia ovidiana se renova e é ressignificada, ao ser relida e reinterpretada em outros contextos. Por isso, "a longa história da recepção da poesia de exílio ovidiana constitui uma parte importante do 'mito' do exílio de Ovídio" (INGLEHEART, 2011, p. 10). ${ }^{8}$ A imagem de Ovídio como exilado não resulta apenas de seus versos, mas especialmente da recepção que deles foi feita a posteriori.

\footnotetext{
${ }^{6}$ Todas as referências ao exílio de Ovídio são posteriores às próprias elegias ovidianas sobre o assunto, podendo, portanto, ter sido motivadas pelos próprios poemas. Williams (2002, p. 341) lista as seguintes fontes antigas sobre o exílio: Plin. HNat. 32, 152; Stat. Sil. I, 2, 253-5; Hier. Chron. 171 g; Aur.-Vict. Caes. I, 24; Sidon. Carm. 23, 158-61. ${ }^{7}$ Não pretendemos discutir a veracidade ou não da ocorrência do exílio ovidiano, mas sua construção no interior do texto. Quando usamos o termo poeta, referimo-nos a uma personagem-poeta, construída no interior do texto e vinculada a uma imagem cultural do poeta exilado, e não ao autor-empírico.

8 " [...] the long history of the reception of Ovid's exile poetry itself forms an important part of the "myth' of Ovid's exile".
} 
Desse modo, propõe-se aqui o tratamento da poesia dos Tristia segundo um enfoque intertextual centrado em sua recepção, abordagem que nos parece inerente aos estudos clássicos, em razão da distância e "defasagem" que nos separam dos antigos. ${ }^{9}$ De fato, nossas leituras da poesia clássica são necessariamente perpassadas por valores, ideias e conceitos de nosso mundo de referência, dos quais não é possível desvencilhar-nos. Isso, todavia, não constitui um anacronismo (no sentido negativo do termo). É simplesmente a condição de leitores situados num contexto histórico-cultural diferente; e, ainda, uma possibilidade de constante ressignificação das produções da Antiguidade, pois é essa defasagem que permite aos clássicos ainda hoje serem lidos. Portanto, enquanto leitores dos antigos, é importante ter "autoconsciência sobre nosso lugar na história da recepção" (EDMUNDS, 2001, p. XIX).

Nessa perspectiva, investigaremos a tradição de poesia de exílio estabelecida por Ovídio a partir da análise de um caso específico de sua recepção: a Elegia III de Camões. Ao apresentar-se como desterrado, Camões adota uma persona ovidiana e, mais do que apenas retomar tópoi das elegias de Ovídio, o poeta português elabora, em seus versos, uma vida de poeta, uma autobiografia literária aos moldes da ovidiana. Conforme comenta Queiroz (1998, p. 152), "é no degredo que Camões escreve os seus Tristes". Ao retomar elementos ovidianos, Camões os ressignifica numa nova perspectiva: suas peregrinações no contexto das grandes navegações e da expansão do império ultramarino português no século XVI. Além disso, Camões contribui para fortalecer a imagem de Ovídio como exilado e, assim, alimentar o "mito" do exílio do poeta e a narrativa literária construída em torno de sua vida.

A análise apresentará um duplo percurso, fundamentada no caráter bilateral do fenômeno da intertextualidade. Por um lado, será

\footnotetext{
${ }^{9}$ Essa noção da "defasagem", em que o termo não tem qualquer valor pejorativo, mas objetiva assinalar nossa separação dos antigos, é desenvolvida por Beard \& Henderson (1998, p. 20): “A Antiguidade clássica é um tema que existe na defasagem entre nós e o mundo dos gregos e romanos. As questões levantadas pelos clássicos são as questões levantadas pela distância que nos separa do mundo 'deles' e, ao mesmo tempo, pela proximidade e familiaridade desse mundo para nós - em nossos museus, em nossa literatura, em nossas línguas, cultura e modos de pensar".
} 
feito um movimento do passado para o presente, a fim de destacar, na lírica de exílio camoniana, elementos da autobiografia literária de Ovídio construída nos Tristia. Por outro, será enfocado um processo de intertextualidade retroativa, já que, segundo Edmunds (2001, p. 23), a repetição intertextual gera também novas leituras acerca do original. ${ }^{10}$ Assim, será possível analisar como os versos de Camões contribuem para a construção da imagem ovidiana de exilado, dando novos sentidos para o "mito" de exílio dos Tristia. Propomos, portanto, uma leitura de Camões via Ovídio e uma leitura de Ovídio via Camões.

\section{A "vida" do poeta e o "mito" do exílio}

Os Tristia, de Ovídio, e as elegias e canções de Camões, obras com um eu poético em primeira pessoa que se autorrepresenta como desterrado, contribuem para construir narrativas da "vida" de ambos os poetas e constituem, portanto, uma espécie de autobiografia literária. Trata-se, evidentemente, de uma imagem da vida da personagem-poeta construída e estilizada textualmente, e não da biografia do autor-empírico.

Opondo-se ao fechamento exclusivo no texto, como era usual na perspectiva neocrítica, Lipking (1984) propõe a noção de "vida do poeta", mas não no sentido de um retorno à biografia ingênua de fundamento causal (a vida como meio para a compreensão da obra), e sim como a "vida" do poeta enquanto poeta (LIPKING, 1984, p. VIII). Ao investigar o que os poetas dizem sobre suas obras e o que as obras dizem sobre os poetas, é possível entrever como um poema pode construir a experiência de uma "vida", a partir da autoprojeção do poeta na obra e de como ele próprio apresenta sua trajetória enquanto poeta (1984, p. IX). ${ }^{11}$

\footnotetext{
${ }^{10}$ Para uma abordagem voltada para a inversão do direcionamento intertextual, vejase Fowler (1997). Isso é algo já discutido por Eliot, em "Tradition and the Individual Talent", e por Borges, em "Kafka e seus precursores".

${ }^{11}$ Apesar da contribuição dessa abordagem, uma de suas limitações consiste no caráter meta-histórico atribuído às "vidas", que, independentemente do poeta a que se referem, apresentariam sempre uma mesma estrutura, centrada em três fases (iniciação, harmonium e tombeau).
} 
A perspectiva de Lipking foi inspiradora para a "crítica de carreiras", um dos ramos do estudo e crítica literária, que "tem como ponto de partida a totalidade da produção textual de um autor e investiga como sua obra, como um todo, se modela, tanto nas relações intratextuais, quanto nas afirmações que ela faz para refletir ou moldar condições de produção extratextuais" (HARDIE; MOORE, 2010, p. 1). ${ }^{12}$ Nessa abordagem, a própria totalidade da obra de um autor é responsável por modelar a carreira poética deste, e a figura do autor é compreendida como mediada por textos, os quais são sempre recebidos por leitores (HARDIE; MOORE, 2010, p. 1). Assim, as carreiras literárias se caracterizam por uma qualidade intensamente intertextual (ou interautorial), na medida em que os escritores têm consciência dos modelos de carreira dos grandes autores do passado e são motivados por ela, seja à emulação, seja à oposição (HARDIE; MOORE, 2010, p. 2).

Essa discussão adquire um elemento a mais na abordagem de Boym (1991), que investiga as relações e limites entre a persona literária, o autor-empírico e também uma personagem cultural do poeta. Segundo a estudiosa (1991, p. 2), "morte" e "vida" dos poetas são construções, e o fazer poético é compreendido como um fazer do "eu", uma "automodelagem" (self-fashioning) poética. Num processo de escrita autoconsciente, o poeta cria sua "vida" e seu "eu" a partir de uma imagem cultural. Com isso, o mito da vida do poeta, de significações culturais, imprime consequências na produção e na recepção literária.

Nesse sentido, abordaremos as autobiografias literárias de Ovídio e de Camões segundo a autoestilização do "eu" empreendida em seus versos, partindo do princípio de que a obra não é um relato da vida empírica, mas uma nova "vida" construída, resultante de um processo de "automodelagem". Nos dois autores, o processo centra-se na tentativa de o poeta construir para si uma máscara que gere a impressão de ser igual ao seu próprio rosto, e o exílio (independentemente de sua real ocorrência) adquire valor literário, torna-se um marco na "vida"

12 "Career criticism takes as its starting point the totality of an author's textual output and aks how that oeuvre as a whole shapes itself, both in its intratextual relationships [...], and in the claims it makes to reflect or mould extratextual conditions of production [...]". 
do poeta, que possibilita um olhar retrospectivo para sua carreira e, com isso, promove a criação de autobiografias literárias. Ademais, na tradição da construção de um “eu” na lírica de exílio, Ovídio pode ser considerado uma espécie de imagem cultural do poeta exilado. Camões cria sua persona com base nessa imagem cultural e, ao fazê-lo, remodela e reestiliza a própria persona ovidiana, de modo que também a recepção participa no processo de "automodelagem" do "eu" e da "vida" do poeta.

A narrativa da "vida" de Ovídio é construída especialmente em suas obras elegíacas: nelas se expressa, em primeira pessoa, uma personagem-poeta que se autodenomina "Nasão"13 (homônima do autorempírico Públio Ovídio Nasão), apresenta-se como poeta e menciona as obras que escrevera. ${ }^{14}$ Assim, empregaremos três nomes diferentes para distinguir três instâncias do "eu": "Públio Ovídio Nasão", que diz respeito ao autor-empírico e que não será objeto das análises; "Nasão", nome do eu poético em primeira pessoa e da personagem-poeta que figura nas obras ovidianas; e "Ovídio", nome de uma personagem cultural, inicialmente depreendida da totalidade da obra do autor, mas conformada também pela história de sua recepção (inclusive pela recepção que, enquanto leitores, aqui construímos).

Num momento inicial da carreira ovidiana, depreendida das informações presentes em suas obras e que constituem sua autobiografia literária, a personagem-poeta se dedica às elegias de temática amorosa e se define como um "poeta do amor". Não obstante, ele logo se vê

${ }^{13}$ As únicas obras em que não figura o nome "Nasão" são os Medicamina faciei femineae (obra que nos chegou fragmentária), as Heroides e as Metamorphoses. Nas Heroides, isso é facilmente justificável pelo fato de não haver uma identificação entre o eu poético das epístolas (heróis e heroínas míticas, além de Safo) e a instância da personagem-poeta. Embora o poeta seja Ovídio, ele transfere sua voz para personagens da tradição mítico-literária, que falam em primeira pessoa e se apresentam como autores das cartas que escrevem. Nas Metamorphoses, por sua vez, a obra escapa ao âmbito elegíaco (ainda que possua diversos elementos elegíacos) e é narrada, com exceção dos quatro versos iniciais do proêmio, em terceira pessoa.

${ }^{14}$ A título de exemplo, nos Amores (2.18.19-26), o eu poético faz referência às Heroides; nos Tristia (2.549-556), menciona os Fastos, a tragédia Medeia (hoje perdida) e as Metamorfoses, além de referir-se frequentemente aos versos eróticos da Ars amatoria que the teriam custado o exílio. 
impulsionado a gêneros poéticos mais elevados, ${ }^{15}$ o que resulta na escrita dos Fasti, da tragédia (perdida) Medea e das Metamorphoses. Essa trajetória de um gênero considerado menor rumo a gêneros maiores ilustra o fato de os poetas romanos, segundo Farrell (2002, apud HARDIE; MOORE, 2010, p. 3), modelarem suas carreiras poéticas nas carreiras políticas de seus patronos, no cursus honorum dos aristocratas romanos, sempre em busca de elevação nos cargos políticos.

Todavia, o cursus da personagem-poeta sofre uma interrupção, assinalada pelo exílio. Independentemente da real ocorrência, o banimento adquiriu significação literária e passou a compor a narrativa da "vida" poética, já que Nasão se apresenta como exilado nas próprias obras. $\mathrm{Na}$ fase final de sua carreira, ele se volta para elegias com temática de exílio, metaforicamente compreendido como uma espécie de "morte" do poeta. Isso é significativo, pois, estando o poeta "morto" em vida, Nasão atribui aos versos de exílio um valor de epitáfio, reunindo neles uma súmula de sua "vida", a fim de garantir sua permanência e imortalidade enquanto poeta entre os pósteros.

Ademais, o exílio ovidiano suscita complexas reflexões acerca das relações entre obra literária e "vida" do poeta. Segundo esclarecimentos do próprio Nasão, sua expulsão de Roma deveu-se a um "poema" e um "erro" - carmen et error (Tristia, 2.207). O error não é em momento algum explicitado, tendo levado à especulação das mais fantasiosas hipóteses. O carmen, por sua vez, é identificado com a Ars Amatoria, poema sobre a arte da conquista e com técnicas de sedução, composto ironicamente sob a forma de um tratado didático. O mais notável é o fato de uma obra literária, a Ars, ter a tal ponto interferido na "vida" do poeta que nela instaurou uma modificação: a relegação de Nasão para o Ponto Euxino. Por sua vez, a nova conformação da "vida" da personagempoeta, agora em desterro, é acompanhada por uma reconfiguração em sua

${ }^{15}$ A oposição entre uma poesia elevada (épica/ trágica) e uma poesia dita menor (elegíaca) era tema comum nos versos dos poetas elegíacos romanos, especialmente na configuração do tópos da recusatio. 
carreira poética: um retorno à escrita elegíaca, mas com a nova temática das dores do exílio. ${ }^{16}$

A narrativa da "vida" que Ovídio constrói ao longo de suas obras irá estruturar, juntamente com a ação da recepção posterior, uma imagem cultural do poeta exilado. No século XVI, essa imagem será apropriada por Camões, que modela seu "eu" como um poeta em desterro e adota uma persona ovidiana especialmente em suas três primeiras elegias ("O poeta Simônides, falando"; "Aquela que de amor descomedido"; "O sulmonense Ovídio, desterrado") e nas canções de número IX e X. ${ }^{17}$ Assim como em Ovídio, na poesia de Camões, o desterro constitui um marco na "vida" do poeta e adquire significação literária, pois promove um olhar retrospectivo em relação às suas vivências e carreira poética anteriores. Nesses poemas, Camões discorre melancolicamente sobre o bem perdido por estar desterrado e revisita, pela ausência, sua lírica amorosa, de modo a apresentar uma complexa narrativa de sua "vida". Essa autobiografia é uma elaboração literária, aspecto que Silva também destaca para a canção X camoniana:

\footnotetext{
${ }^{16}$ Embora esses nexos entre obra e vida possam ser, em alguma medida, causais e, por isso, aparentar uma retomada de biografismo ingênuo, quase que num movimento circular de abandono e posterior retorno à biografia, nossa perspectiva distinguese do enfoque ingênuo pela autoconsciência acerca do fenômeno, que passa a ser compreendido como literário. Nesse sentido, há que se ter consciência de que as "vidas" construídas são vidas de poetas, autobiografias poéticas, e não a vida real de um autor-empírico. E ainda que a narrativa final da "vida" da personagem-poeta não se diferencie muito da suposta biografia geralmente narrada do autor-empírico, a mudança de perspectiva na abordagem do fenômeno revela um processo completamente diferente, que promove um movimento interpretativo capaz de gerar discussões e reflexões sobre o fazer literário e a feitura do "eu".

${ }^{17}$ Para a numeração e citação de trechos da obra lírica de Camões, seguimos a edição das Rimas estabelecida por Costa Pimpão (1953). Segundo Silva (1999, p. 57-58), “o Prof. Costa Pimpão representa um momento decisivo da crítica textual camoniana, porque teve a coragem, fundada em boas razões, para romper frontalmente com a herança de Faria e Sousa, tanto no que diz respeito às atribuições de autoria como no atinente à fixação do texto, consumando assim a reacção que desde Storck e Carolina Michaëlis de Vasconcelos se vinha desenvolvendo contra aquele autor seiscentista, editor e exegeta da obra de Camões".
} 
Só uma leitura ingénua ou estreitamente biografista pode interpretar essa história como a narrativa autobiográfica de eventos efectivamente acontecidos. Essa história está inscrita no modelo da lírica europeia desde o século XV até o século XVII - o modelo petrarquiano e petrarquista - e o seu significado poético, antropológico e metafísico tem de ser construído à luz do neoplatonismo e do petrarquismo. A poesia de Camões [...] é a construção poética de uma autobiografia na tessitura da qual ficção e realidade, memória literária e memória vivencial, fantasmas da imaginação e acontecimentos verídicos se mesclam e se fundem. (SILVA, 1999, p. 223-224)

O tenso jogo entre realidade e ficção e as complexidades da escrita autobiográfica são algo que já remonta a Ovídio. A poesia de Camões, enquanto construto poético de uma autobiografia que se fundamenta em memórias intertextuais, apresenta pontos de contato não apenas com a lírica europeia de matriz petrarquista, como destaca Silva, mas também dialoga com a poesia de exílio ovidiana. Com isso, a narrativa da "vida" camoniana se insere na tradição de uma lírica de exílio que tem Ovídio como um dos expoentes.

\section{A persona ovidiana de Camões na Elegia III}

A adoção de uma persona ovidiana por Camões em parte de sua produção lírica é assinalada explicitamente na Elegia III. A crítica, em geral, assume que o poema teria sido escrito em Portugal, ${ }^{18}$ muito embora o eu poético adote a máscara de exilado e se identifique com Ovídio. Um

${ }^{18}$ Cidade (1967, p. 46) propõe que o poema foi escrito perto de Lisboa: "O fato de ao sulmonense Ovídio, a cuja dor compara a sua, ter sido infligida a pena do desterro não mostra necessariamente que a Camões o houvesse sido. A fantasia do Poeta terá, porventura, exagerado uma ausência num desterro [...] nas proximidades de Lisboa, nas margens do Tejo". Pereira (2004, p. 112) considera a Elegia III o primeiro poema de degredo escrito por Camões. O "exílio" camoniano e suas causas são questões controversas. Queiroz (1998, p. 151) menciona que, mesmo tendo obtido uma "carta de Perdão" por ter ferido um empregado do palácio, Camões parte para a Índia numa 
primeiro elemento de aproximação consiste na própria escrita de elegias ${ }^{19}$ pelo poeta português, visto que toda a obra ovidiana, com exceção das Metamorfoses, pertence ao gênero elegíaco. Ademais, há na Elegia III a citação explícita, no verso inicial, do nome de Ovídio, seguida de sua detalhada descrição como poeta desterrado:

\author{
O Sulmonense Ovídio, desterrado \\ na aspereza do Ponto, imaginando \\ ver-se de seus parentes apartado; \\ sua cara mulher desamparando, \\ seus doces filhos, seu contentamento, \\ de sua pátria os olhos apartando; \\ não podendo encobrir o sentimento, \\ aos montes e às águas se queixava \\ de seu escuro e triste nacimento. \\ O curso das estrelas contemplava, \\ e como por sua ordem discorria \\ o céu, o ar e a terra adonde estava. \\ Os peixes pelo mar nadando via, \\ as feras pelo monte, procedendo \\ como seu natural lhes permitia. \\ De suas fontes via estar nascendo \\ os saudosos rios de cristal, \\ a sua natureza obedecendo.
}

espécie de autoexílio. Independentemente das condições do degredo camoniano, o que se observa é uma autorrepresentação do poeta em seus versos como degredado. ${ }^{19}$ As elegias de Camões estruturam-se em terza rima, esquema métrico que, segundo Silva (2012, p. 22), foi consagrado pelo uso de Sannazaro e dos poetas italianos como equivalente ao dístico elegíaco. Em termos formais, cada dístico das elegias antigas constitui-se como uma unidade, assim como cada terceto nesse novo esquema rítmico. Evidentemente, há diferenças nos elementos definidores do gênero elegíaco em Ovídio e em Camões (mesmo na Antiguidade greco-romana, o dístico elegíaco podia abarcar produções poéticas bastante diversificadas). Todavia, são bastante significativas, como elementos de identificação, a adoção de uma forma poética de mesmo nome e a coincidência dos temas principais (amor e exílio). Segundo Silva (2012, p. 22), havia dois modelos de elegia renascentista - fúnebre e amorosa -, cuja temática principal era o lamento. Ora, na Antiguidade, a obra de Ovídio reunia essas duas tradições, ao abordar o amor nas elegias amorosas e a morte nas elegias de exílio. Para mais detalhes sobre elegia e gênero elegíaco na tradição e em Camões, veja-se Silva (2012). 
Assi só, de seu próprio natural

apartado, se via em terra estranha,

a cuja triste dor não acha igual.

Só sua doce Musa o acompanha,

nos versos saudosos que escrevia,

e lágrimas com que ali o campo banha.

(CAMÕES, Elegia III, 1953, p. 259-260. Grifos nossos)

O trecho sintetiza várias das experiências de exílio expostas por Nasão nos Tristia. ${ }^{20}$ Camões retoma informações da poesia ovidiana e elabora uma narrativa desse exílio, de modo a apresentar uma imagem de Ovídio como poeta exilado. Além de denominá-lo “desterrado" (v. 1) e descrever sua situação como uma separação da terra pátria e dos entes queridos, conforme assinala o emprego frequente do verbo apartar (v. 3, 6, 20), o estatuto de poeta fica marcado pela menção à Musa e à natureza dos versos escritos no Ponto: são queixas saudosas, banhadas de lágrimas (v. 22-24).

A ideia da Musa como única companheira no exílio é tema recorrente nos Tristia: "Também a mim, condenado ao Ponto, a Musa conforta;/ só ela persiste companheira de meu desterro" (OVÍDIO, Tristia 4.1.19-20) e "Agradeço-te, ó Musa! Pois tu dás consolos,/ tu és repouso à dor, tu vens como remédio;/ tu és guia e companheira; tu me afastas do Istro/ e me dás lugar no meio do Hélicon" (OVÍDIO, Tristia 4.10.117-120). ${ }^{21}$ Ela designa, metonimicamente, a própria poesia, que se torna o meio para confortar as dores e aliviar os sofrimentos de se estar

\footnotetext{
${ }^{20}$ A Elegia III de Camões é analisada comparativamente com a poesia de exílio ovidiana por Pereira (2004, p. 109-112), que elenca tópoi e trechos comuns, alguns dos quais retomaremos em nossa análise, como o tópos do isolamento, do clima inóspito e do consolo propiciado pela escrita (PEREIRA, 2004, p. 108). Estudo detalhado da Elegia III foi feito por Yahn (1981), cujo foco principal não é o diálogo com Ovídio, mas a abordagem de elementos do neoplatonismo humanista em Camões.

${ }^{21}$ Me quoque Musa leuat Ponti loca iussa petentem;/ sola comes nostrae perstitit illa fugae. - Gratia, Musa, tibi! Nam tu solacia praebes,/ tu curae requies, tu medicina uenis;/ tu dux et comes es; tu nos abducis ab Histro, / in medioque mihi das Helicone locum. As citações em latim seguem o texto-base estabelecido por André (2008). Todas as traduções de trechos em latim para o português são de nossa responsabilidade.
} 
distante, em terra hostil. Não por acaso, a Musa ovidiana é qualificada por Camões como "doce" (v. 22). O adjetivo, porém, adquire uma segunda significação caso se considere o contexto da poesia elegíaca romana. Termos como dulcis ("doce"), mollis ("macio"), tener ("brando"), leuis ("leve") e exiguis ("exíguo") eram usados pelos elegíacos com valor programático, para caracterizar a elegia em oposição à épica. ${ }^{22}$ Nessa perspectiva, a "doce Musa" que, segundo Camões, acompanha Ovídio diz respeito a um tipo específico de poesia, a elegíaca.

Os dois tercetos iniciais tematizam o momento de separação, os instantes em que Ovídio por último vê a pátria antes de partir para o desterro. O verbo "imaginando" (v. 2) demarca que os fatos são entrevistos como memórias pelo poeta já exilado, do mesmo modo como ocorre na elegia 1.3 dos Tristia. Nesse poema, Nasão, já distante de Roma, narra em detalhes sua última noite na Urbe e a despedida da esposa, a partir das imagens que lhe vêm à mente, tristes lembranças da partida: "Quando me vem à mente a tristíssima visão daquela noite,/ que foi meu último instante em Roma,/ quando recordo a noite em que deixei tantas coisas queridas, / ainda agora lágrimas escorrem de meus olhos" (OVÍDIO, Tristia 1.3.1-4). ${ }^{23}$

Diante do sofrimento de estar banido, o Ovídio camoniano lamenta e maldiz o dia de seu "escuro e triste nascimento" (v. 9). Também isso é assunto nos Tristia, quando Nasão afirma, na terra de exílio, que "até aqui conheço os fios de meu nascimento,/ fios fiados para mim de negra lã" (OVÍDIO, Tristia 4.1.63-64). ${ }^{24} \mathrm{~A}$ sombra que marcou o nascimento do poeta contamina os fios de seu fado e se concretiza no sombrio banimento.

Nos tercetos seguintes, estabelece-se uma oposição entre o movimento e a ordem natural das coisas - os astros no céu, os peixes no mar e os animais na terra, os rios seguindo seu curso - e o desacordo do

\footnotetext{
22 Para mais detalhes sobre adjetivos programáticos usados pelos poetas romanos, veja-se Boyle (1993, p. 2-5).

${ }^{23}$ Cum subit illius tristissima noctis imago/ quae mihi supremum tempus in Vrbe fuit,/ cum repeto noctem, qua tot mihi cara reliqui,/ labitur ex oculis nunc quoque gutta meis. ${ }^{24}$ hic quoque cognosco natalis stamina nostri,/ stamina de nigro uellere facta mihi.
} 
poeta exilado em relação a elas, pois está "de seu próprio natural apartado" (v. 19-20) e em "terra estranha". Esse estranhamento quanto ao ambiente de exílio é por vezes realçado nos Tristia, e talvez o melhor exemplo disso seja a elegia 3.3, quando Nasão escreve à esposa queixando-se por estar doente. Seu estado debilitado resulta das péssimas condições do lugar, completamente impróprias e avessas ao "natural" de Nasão. ${ }^{25}$

É curioso, todavia, que, na elegia de Camões, a natureza do local de exílio ovidiano parece estar em acordo consigo mesma, diferentemente do que se passa nos Tristia, em que a região do Ponto caracteriza-se por eventos extremos e surpreendentes, verdadeiras mirabilia, que a aproximam do âmbito mitológico. O curso das estrelas, que na versão camoniana "em ordem discorria" (v. 11), adquire aspecto aterrorizador nos Tristia: Nasão situa-se sob a constelação da Ursa ou sob a órbita licaônia. ${ }^{26}$ Segundo Videau-Delibes (1991, p. 141), esses astros fazem referência às personagens mitológicas de Calisto e Licaão, metamorfoseados respectivamente em ursa e lobo, animais ferozes e vis, que presidem com sua bestialidade o destino do lugar de exílio.

Mais significativo é o fato de Camões afirmar que Ovídio via peixes nadando no mar conforme seu natural lhes permitia (v. 13-15). Na elegia 3.10 dos Tristia, em que Nasão descreve o rigoroso inverno em Tomos, o frio extremo é responsável por cobrir de gelo a barba e os cabelos dos habitantes bárbaros, congelar o vinho sem que seja necessário contê-lo em jarras e solidificar o rio Istro, que passa a ser atravessado por carruagens. Uma das imagens mais chocantes do poema consiste no

${ }^{25}$ OVÍDIO, Tristia 3.3.7-14: Nec caelum patior nec aquis adsueuimus istis, / terraque nescio quo non placet ipsa modo./ Non domus apta satis, non hic cibus utilis aegro, / nullus Apollinea qui leuet arte malum, / non qui soletur, non qui labentia tardel tempora narrando fallat, amicus adest./ Lassus in extremis iaceo populisque locisque, / et subit adfecto nunc mihi, quicquid abest. - "Não tolero os ares nem me habituei a essas águas,/ e a terra, não sei por que, tampouco me agrada./ Aqui não há casa bastante adequada, nem alimentos próprios ao doente,/ ninguém que alivie o mal com a arte de Apolo,/ nenhum amigo que me console, ou que engane/ com sua conversa o tempo que escorre lento./ Exausto, jacente entre povos e locais extremos,/ invade-me, agora doente, a lembrança do que dista".

${ }^{26}$ OVÍDIO, Tristia 3.2.2; 3.4b.1-2; 3.10.3-4; 3.11.8; 4.9.17-18; 5.3.7. 
mar congelado pelo frio, a ponto de os peixes não mais nadarem, mas aderirem-se ao gelo: "Vi o imenso mar tornar-se gelo,/ e uma crosta escorregadia premia as águas imóveis./ Não basta ter visto: pisei o duro mar,/ e a superfície da água ficou sob o pé não molhado. [...] Vi peixes, presos, se aderirem ao gelo,/ e parte deles ainda estava viva" (OVÍDIO, Tristia 3.10.37-40; 49-50). ${ }^{27}$

$\mathrm{Na}$ elegia de Camões, por sua vez, o curso da natureza é organizado, e a desordem centra-se na interioridade do sujeito. Com isso, Camões interpreta e recria Ovídio segundo um elemento característico de sua própria poesia: a indiferença do curso da natureza diante do desconcerto do sujeito no mundo. A realização de uma (re) leitura especificamente camoniana da situação de Ovídio é um dos procedimentos para o eu poético identificar-se com a persona ovidiana. Essa aproximação é reforçada pelo fato de toda a narrativa sobre Ovídio constituir um símile. $O$ terceto que segue imediatamente a longa descrição da condição do poeta romano é introduzido pela expressão "dest'arte" (v. 25), responsável por estabelecer a comparação entre os dois poetas e igualar suas experiências enquanto exilados:

Dest' arte me afigura a fantasia

a vida com que vivo, desterrado

do bem que noutro tempo possuía.

(CAMÕES, Elegia III, 1953, p. 260. Grifos nossos)

De acordo com Yahn (1981, p. 36), as estrofes iniciais sobre Ovídio e seu desterro funcionam como um "microtexto", "uma espécie de operador metalinguístico", pois a narrativa de Camões, na verdade, acaba por descrever a situação atual do eu lírico. Portanto, instaura-se uma escrita em abismo, bem ao gosto do espelhamento maneirista da época de Camões (YAHN, 1981, p. 36). Assim como Ovídio exilado é descrito imaginando momentos passados e aquilo que perdeu ao ser expulso de Roma, o eu poético camoniano vive na "fantasia" (v. 25),

27 Vidimus ingentem glacie consistere pontum,/ lubricaque inmotas testa premebat aquas./ Nec uidisse sat est, durum calcauimus aequor/ undaque non udo sub pede summa fuit. [...] Vidimus in glacie pisces haerere ligatos, / sed pars ex illis tum quoque uiua fuit. 
"desterrado do bem" (v. 26-27), que só lhe permanece em mente, por meio das reminiscências.

Nos Tristia, o tópos da "visão da mente" é responsável por dar presença àquilo que está ausente. Por meio de vívidas descrições, Nasão recria em pensamento imagens da Urbe e as expressa em seus versos, como o triunfo sobre a Germânia na elegia 4.2, as construções e monumentos de Roma nas elegias 1.1 e 3.1 e mesmo a narração dos eventos na noite de sua partida para o exílio, na elegia 1.3. Por meio do procedimento da enárgeia (euidentia ou illustratio, em latim), ${ }^{28}$ que se define por trazer à luz e pôr diante dos olhos aquilo descrito por palavras, Nasão, desterrado, através da poesia, revive e relembra Roma.

De modo similar, Camões afirma na Elegia III levar uma vida de "fantasia", viver na imaginação daquilo que está ausente. Na Antiguidade, phantasia associa-se ao campo semântico da visão e da luz e diz respeito às imagens criadas para os olhos da mente, de forma a envolver toda uma teorização sobre imagens mentais. ${ }^{29}$ A partir do período medieval, porém, a fantasia passa a ser vista, segundo Agamben (2007, p. 22-25), como uma das manifestações do sentimento de "acídia-tristeza" que acometia os monges em suas celas e era considerado um dos pecados capitais pelos Padres da Igreja. A acídia, espécie de torpor desalentado, desânimo apático causador de inércia de atitude e agitação interior, tem como uma de suas manifestações, a euagatio mentis, ${ }^{30}$ "a fuga do ânimo diante de si e o inquieto discorrer de fantasia em fantasia", que revela a "incapacidade de controlar o incessante discurso (a co-agitatio) dos fantasmas interiores" (AGAMBEN, 2007, p. 25). ${ }^{31}$

\footnotetext{
${ }_{28}$ Para detalhes sobre enárgeia/euidentia e comentários de autores antigos grecoromanos sobre o fenômeno, vejam-se Zanker (1981) e Frias (2009). Para a enárgeia nas obras ovidianas, Hardie (2006).

${ }^{29}$ A discussão sobre phantasia não se limita ao âmbito literário e está presente também na retórica e na filosofia. O termo ocorre, por exemplo, nas reflexões de Platão e de Longino. Para mais detalhes, Frias (2009).

${ }^{30}$ Segundo Gregório, eram seis as filhas da acídia: malitia, rancor, pusillanimitas, desperatio, torpor circa praecepta, euagatio mentis (AGAMBEN, 2007, p. 24).

${ }^{31}$ Para mais descrições da acídia, vejam-se Agamben (2007, p. 21-32) e suas referências.
} 
No contexto do Humanismo italiano, ao qual se vinculam várias ideias da poesia camoniana, a acídia foi reinterpretada e associada à melancolia. Identificada como um dos quatro humores (flegmático, sanguíneo, colérico e melancólico) do homem desde a doutrina hipocrática, a melancolia (ou bile negra) adquire no Renascimento, segundo Silva (1999, p. 209), novos significados e usos simbólicos, iconológicos e poéticos. Ampla teorização sobre o assunto foi empreendida por Marsílio Ficino, que, no pensamento neoplatônico florentino, compreende a melancolia como o humor mais propício para a criação artística, mas também como um dom divino dispensado por Saturno e marcado por polaridade ambígua, pois pode envolver tanto a exaltação da energia criadora, quanto uma influência maligna e funesta para o homem. ${ }^{32}$

Diante disso, a "fantasia" a que se refere o eu poético, mais do que imagem mental daquilo que está ausente, é memória recorrente e atormentada do que foi perdido, ${ }^{33}$ sendo a perda o que move o sentimento melancólico. Nesse sentido, o desterro camoniano não é tanto de caráter espacial (como o afastamento da pátria lamentado por Ovídio), mas de natureza sobretudo espiritual: o eu poético está "desterrado/ do bem", separação formalmente assinalada pelo enjambement do verso. Numa perspectiva neoplatônica, o Bem se vincula a um estado de graça e amor, capaz de ultrapassar o mundo sensível e elevar o espírito ao mundo inteligível, e, na lírica de Camões, relaciona-se frequentemente à figura da mulher amada.

A ausência resultante da perda é destacada nos três tercetos seguintes, pela anáfora de "ali" (v. 28, 31 e 34), que desloca para outro tempo o bem perdido; tempo que encerra "o gosto já passado", "a caduca e débil glória" e a "lembrança", signos da perda inevitável, posto que a vida é frágil e feita de mudança (v. 32-33). O temperamento melancólico manifesta-se nas atitudes do eu poético:

\footnotetext{
${ }^{32}$ Para um comentário detalhado e mais referências sobre a melancolia no Humanismo e no Renascimento, veja-se Amaral (2007, p. 57-65).

${ }^{33}$ A agitação e o tormento que perseguem o melancólico e lhe preenchem toda a mente em incessante pensar manifestam-se na sequência da elegia, em que o eu poético afirma não descansar sequer no sono e, acordado, estar em desacordo com o mundo (v. 43-48).
} 
dali me vou com passo carregado, a um outeiro erguido, e ali me assento, $\quad 50$ soltando a rédea toda a meu cuidado.

Despois de farto já de meu tormento, dali estendo os olhos saudosos à parte aonde tenho o pensamento.

Não vejo senão montes pedregosos; 55 e os campos sem graça e secos vejo que já floridos vira e graciosos. (CAMÕES, Elegia III, 1953, p. 260-261. Grifos nossos)

Seu passo é "carregado", voltado para a terra, elemento associado à melancolia. Os olhos, saudosos, buscam aquilo que foi perdido e vive apenas em memória. No trecho, as fantasias e imagens vistas com os olhos da mente parecem materializar-se concretamente na paisagem observada. Se, por um lado, fica a perdida lembrança de campos floridos e graciosos, por outro, o ambiente que cerca o eu poético, contemplado por olhos de melancólico, assume as características da melancolia: os montes são pedregosos, e os campos são sem graça e secos. A secura, a aridez, o aspecto terroso e pedregoso, o desânimo e a indisposição que tornam a paisagem sem graça são elementos vinculados ao temperamento melancólico. ${ }^{34}$

O eu poético camoniano dos poemas de desterro sofre do "mal de ausência" (Elegia II, v. 86), e em seus versos são frequentes os termos que remetem à tristitia, como "triste", "tristeza" e "tristura" (SILVA, 1999, p. 215), o que o aproxima de Ovídio e dos Tristia (“Tristezas”). A identificação ocorre não apenas pela adoção de uma persona ovidiana por Camões, mas também, em sentido inverso, pela atribuição de traços camonianos ao exílio de Ovídio, numa releitura de sua imagem. Assim, ao

\footnotetext{
${ }^{34}$ Isso fica ainda mais evidente na Canção IX, em que o local de desterro é descrito como "junto de um seco, fero e estéril monte" (v. 1), e toda sua natureza caracterizada por meio de negações: "onde nem ave voa, ou fera dorme,/ nem rio claro corre, ou ferve fonte,/ nem verde ramo faz doce ruído" (v. 4-6). A aspereza e dureza da terra assinalam o caráter melancólico do eu poético, e sua vida "em pedaços repartida" (v. 30 ), dividida pelo mundo, demarca a imagem de desterrado.
} 
referir-se à "aspereza do Ponto" (v. 2), Camões descreve o local de exílio ovidiano com base em seu próprio desterro, marcado pela melancolia.

Não obstante, o mundo de pedras, aridez e aspereza é contrastado com a natureza bela, mas ausente, representada pelo rio Tejo:

Vejo o puro, suave e brando Tejo, com as côncavas barcas, que, nadando, vão pondo em doce efeito seu desejo. $\quad 60$

Ũas co brando vento navegando, outras cos leves remos, brandamente as cristalinas águas apartando.

(CAMÕES, Elegia III, 1953, p. 261. Grifos nossos)

O trecho é fortemente metapoético. Desde a Antiguidade, a imagem da água (seja uma fonte transbordante, seja um rio fluindo) associa-se à atividade e à inspiração poética. Igualmente, era comum na poesia latina a metáfora do barco em movimento (como subcategoria da metáfora de viagem) para designar a escrita poética. ${ }^{35}$ Nessa perspectiva, se, por um lado, o rio Tejo aponta para o bem perdido pelo eu poético desterrado, por outro, ele pode designar a própria escrita elegíaca. Os vários termos para fazer referência ao rio e seus entornos - "suave e brando" (v. 58), "doce" (v. 60), "brando" (v. 61), "leves" e "brandamente" (v. 62) - eram termos programáticos para identificar em contexto romano a poesia elegíaca, especialmente de temática amorosa.

Todavia, o eu poético apenas contempla as águas brandas e suaves do Tejo. Estando desterrado, a metáfora da água para a atividade poética funda-se numa nova imagem: a das lágrimas. Num sentido metapoético, elas designam os próprios versos camonianos, "longa e mísera escritura" (Elegia I, v. 66), versos de lamento e saudade:

Dali falo co a água, que não sente com cujo sentimento a alma sai 65 em lágrimas desfeita claramente.

\footnotetext{
${ }^{35}$ A respeito dessas metáforas de viagem, vejam-se Sharrock (1994, p. 96-99) e Volk (2002, p. 20-21).
} 
Ó fugitivas ondas, esperai! que, pois me não levais em companhia, ao menos estas lágrimas levai,

até que venha aquele alegre dia

que eu vá onde vós is, contente e ledo.

Mas tanto tempo quem o passaria?

(CAMÕES, Elegia III, 1953, p. 261. Grifos nossos)

A fala do eu poético com a água insere-se na elegia com a apostrofação das "fugitivas ondas" (v. 67), às quais ele dedica "estas lágrimas" (v. 69) - seus próprios versos -, rogando ao Tejo que as leve para o local de onde ele próprio está apartado e impedido de ir. Também aqui se nota uma aproximação em relação à imagem de Ovídio construída no início da elegia. Conforme destaca Pereira (2004, p. 112), assim como Camões agora apostrofa as águas do Tejo, o poeta latino, na versão camoniana, “aos montes e às águas se queixava” (v. 8). Embora o lamento às águas seja uma inovação camoniana, nos Tristia observase a apostrofação, não às águas, mas ao livro que Nasão envia a Roma, aonde ele está proibido de ir: "Livrinho - não te invejo - sem mim irás a Roma:/ ai de mim! pois não é lícito ao teu amo ir. [...] Parte, livro, e saúda em meu nome os locais queridos!/ Decerto irei tocá-los ao menos com o pé permitido" (OVÍDIO, Tristia 1.1.1-2; 15-16). ${ }^{36}$

Para o eu poético camoniano, assim como para Nasão, ${ }^{37}$ não há esperança de fim do degredo antes da morte: "porque primeiro a vida acabará/ que se acabe tão áspero degredo" (CAMÕES, Elegia III, 1953, p. 261). Diante disso, ele se entrega à imaginação da própria morte e antecipa imagens do submundo, do Tártaro e do Lete. É bem significativa a menção deste último, rio do esquecimento, pois estabelece

\footnotetext{
${ }^{36}$ Parue - nec inuideo - sine me, liber, ibis in Vrbem:/ ei mihi! quod domino non licet ire tuo. [...] Vade, liber, uerbisque meis loca grata saluta!/ Contingam certe quo licet illa pede.

${ }^{37}$ OVÍDIO, Tristia 3.3.33-34; 37-38: Vel poena in tempus mortis dilata fuisset,/ uel praecepisset mors properata fugam!/ [...] Tam procul ignotis igitur moriemur in oris/ et fient ipso tristia fata loco. - "Ou que a pena tivesse sido diferida para a hora da morte,/ ou a morte, prematura, tivesse precedido o desterro!/ [...] Tão longe, então, em praias desconhecidas, morrerei,/ e o próprio local fará tristes os fados".
} 
nítido contraste com a menção do Tejo, rio que lembra o eu poético das recordações do passado.

A visão mental da morte, porém, só traz pesar e tristeza, pois põe em realce a impossibilidade do fim do desterro e a vida baseada na fantasia melancólica, pois a Camões não é possível esquecer, apenas viver de triste saudade, imaginando o que se perdeu: "Esta imaginação me acrescenta/ mil mágoas no sentido, porque a vida/ de imaginações tristes se sustenta" (CAMÕES, Elegia III, 1953, p. 261). Ovídio, por sua vez, diante da impossibilidade de retorno, não apenas não se esquece da cara pátria, mas ainda se esforça para ser lembrado por meio de seus versos, que envia à posteridade (Tristia 4.10.1-2). A posteridade os recebeu e se lembrou do poeta exilado; ela os releu, recriou e fixou o "mito" do exílio ovidiano.

\section{Referências}

AGAMBEN, G. Estâncias: a palavra e o fantasma na cultura ocidental. Tradução de Selvino Assmann. Belo Horizonte: Editora UFMG, 2007.

AMARAL, S. A. P. do. Desavenças: poesia, poder e melancolia nas obras do doutor Francisco de Sá de Miranda. 2007. 317 f. Tese (Doutorado em História Social) - Faculdade de Filosofia, Letras e Ciências Humanas da Universidade de São Paulo, São Paulo, 2007.

BEARD, M.; HENDERSON, J. Antiguidade clássica: uma brevíssima introdução. Tradução de Marcus Penchel. Rio de Janeiro: Jorge Zahar Editor, 1998.

BORGES, J. L. Kafka e seus precursores. In: . Outras inquisições. Tradução de Davi Arrigucci Jr. São Paulo: Companhia das Letras, 2007. p. 127-130. [1951]

BOYLE, A. J. Introduction: the Roman Song. In: . (Ed.). Roman Epic. London: Routledge, 1993. p. 1-18.

BOYM, S. Death in Quotation Marks: Cultural Myths of the Modern Poet. Cambridge/London: Harvard University Press, 1991. 
CAMÕES, L. de. Rimas. Texto estabelecido e prefaciado por Álvaro Pimpão. Coimbra: Acta Universitatis Conimbrigensis, 1953. Disponível em: <https://books.google.com.br/books?id=5E6KJh5Svj8C\&printsec $=$ frontcover\&hl $=$ pt-BR\&source $=$ gbs ge summary $\mathrm{r} \& \mathrm{cad}=0 \# \mathrm{v}=$ onepa ge \&q\&f=false $>$. Acesso em: 03 nov. $201 \overline{7}$.

CLAASSEN, J.-M. Ovid's Poems from Exile: the Creation of a Myth and the Triumph of Poetry. In: DIHLE, A.; HARMS, W. et al. (Ed.). Antike und Abendland: Beiträge zum Verständnis der Griechen und Römer und ihres Nachlebens. Berlin/New York: Walter de Gruyter, 1988, Band XXXIV. p. 158-169.

CLAASSEN, J.-M. Tristia. In: KNOX, P. (Ed.). A Companion to Ovid. Malden; Oxford: Wiley-Blackwell, 2009. p. 170-183.

EDMUNDS, L. Intertextuality and the Reading of Roman Poetry. Baltimore/London: The Johns Hopkins University Press, 2001.

ELIOT, T. S. Tradition and the Individual Talent. In: . Selected Essays. London: Faber and Faber Limited, 1934. p. 13-22.

FITTON BROWN, A. D. The Unreality of Ovid's Tomitan Exile. Liverpool Classical Monthly, Liverpool, v. 10, n. 2, p. 18-22, 1985.

FOWLER, D. On the Shoulders of Giants: Intertextuality and Classical Studies. Materiali e discussioni per l'analisi dei testi classici, Pisa/Roma, n. 39, p. 13-34, 1997.

FRIAS, J. M. A retórica da visão na Poética Clássica. Estudos em homenagem a Ana Paula Quintela. Porto: Universidade do Porto, 2009. p. 25-42.

HARDIE, P.; MOORE, H. (Ed.). Classical Literary Careers and their Reception. Cambridge: Cambridge University Press, 2010.

HARDIE, P. Ovid's Poetics of Illusion. Cambridge: Cambridge University Press, 2006. [2002]

INGLEHEART, J. Two Thousand Years of Solitude: Exile After Ovid. New York: Oxford University Press, 2011.

LIPKING, L. The Life of the Poet: Beginning and Ending Poetic Careers. Chicago: University of Chicago Press, 1984. 
OVIDE. Tristes. Texte établi et traduit par Jacques André. Paris: Les Belles Lettres, 2008.

PEREIRA, M. H. da R. A Elegia III de Camões. Península-Revista de Estudos Ibéricos, Porto, n. 1, p. 107-112, 2004.

QUEIROZ, M. J. de. Camões, o peregrino, o vago, o errante. In:

Os males da ausência ou A literatura do exílio. Rio de Janeiro: Topbooks, 1998. p. 149-157.

SHARROCK, A. Seduction and Repetition in Ovid's Ars Amatoria II. Oxford: Clarendon Press, 1994.

SILVA, V. A. e. A elegia na lírica de Camões. In: PEREIRA, S.; FERRO, M. (Coord.). Actas da VI Reunião Internacional de Camonistas. Coimbra: Imprensa da Universidade de Coimbra, 2012. p. 19-31.

SILVA, V. A. e. Camões: labirintos e fascínios. Lisboa: Cotovia, 1999.

VIDEAU-DELIBES, A. Les Tristes d'Ovide et l'élégie romaine: une poétique de la rupture. Paris: Klincksieck, 1991.

VOLK, K. The Poetics of Latin Didactic: Lucretius, Vergil and Manilius. Oxford: Oxford University Press, 2002.

WILLIAMS, G. Ovid's Exilic Poetry: Worlds Apart. In: BOYD, B. W. (Ed.). Brill's Companion to Ovid. Leiden; Boston; Köln: Brill, 2002. p. 337-381.

WILLIAMS, G. Ovid's Exile Poetry: Tristia, Epistulae ex Ponto and Ibis. In: HARDIE, P. (Ed.). The Cambridge Companion to Ovid. Cambridge: Cambridge University Press, 2006. p. 233-245.

YAHN, G. G. B. O homem sob o signo do desterro: uma elegia de Camões. Rio de Janeiro: Real Gabinete Português de Leitura, 1981.

ZANKER, G. Enargeia in the Ancient Criticism of Poetry. Rheinisches Museum für Philologie, New Folge, v. 124, n. 3/4, p. 297-311, 1981.

Recebido em: 23 de abril de 2018. Aprovado em: 22 de maio de 2018. 